\title{
Sex-dependent differences in the activities of acetylsalicylic acid- esterases in mouse kidneys
}

M.A.C. Benedito
Departamento de Psicobiologia, Escola Paulista de M edicina, Universidade Federal de São Paulo, São Paulo, SP, Brasil

\section{Correspondence}

M.A.C. Benedito

Departamento de Psicobiologia EPM, UNIFESP

Rua Botucatu, 861, 10 andar 04023-062 São Paulo, SP

Brasil

Fax: + 55-11-572-5092

Research supported by CNPq and AFIP. Publication supported by FAPESP.

Received M arch 20, 1998 Accepted November 27, 1998

\section{Abstract}

Acetylsalicylic acid (ASA), the most used drug worldwide, is hydrolyzed to salicylic acid and acetate by esterases present in tissues of several species including humans. Sex differences in drug metabolism by rodent liver are documented in the literature. In this paper we report a difference in the activities of the esterases (ASA-esterase I and II) in the kidneys of male and female mice. In this species there is no difference between males and females in liver ASA-esterases (ASAesterase I: males $38.5 \pm 7.9(\mathrm{~N}=5)$ and females $31.6 \pm 7.6(\mathrm{~N}=5) \mathrm{nmol}$ of salicylic acid formed $\mathrm{min}^{-1} \mathrm{mg}$ protein ${ }^{-1}, \mathrm{P}>0.05$; ASA-esterase II: males $77.3 \pm 17.4(\mathrm{~N}=5)$ and females $61.4 \pm 15.1(\mathrm{~N}=5) \mathrm{nmol}$ of salicylic acid formed $\mathrm{min}^{-1} \mathrm{mg}$ protein $\left.{ }^{-1}, \mathrm{P}>0.05\right)$. However, in the kidneys males presented a much higher enzyme activity than females (ASA-esterase I: males $25.2 \pm 6.3(\mathrm{~N}=5)$ and females $6.8 \pm 0.6(\mathrm{~N}=$ 5) nmol of salicylic acid formed $\mathrm{min}^{-1} \mathrm{mg}_{\text {protein }}{ }^{-1}, \mathrm{P}<0.0002$; ASAesterase II: males $79.8 \pm 10.1(\mathrm{~N}=5)$ and females $13.0 \pm 1.1(\mathrm{~N}=5)$ $\mathrm{nmol}$ of salicylic acid formed $\mathrm{min}^{-1} \mathrm{mg}$ protein $\left.{ }^{-1}, \mathrm{P}<0.0001\right)$. The difference between sexes observed in mouse kidneys could serve as a model to study the molecular basis of this sex difference and also to determine the possible involvement of pituitary and gonadal hormones in this difference in ASA-esterase activities since these hormones control the sex differences in rodent liver enzyme activity.
Key words

- Acetylsalicylic acid

- Esterases

- Mice

- Sex differences

- Kidneys

- Liver

\section{Introduction}

Sexual dimorphism in the activity of enzymes involved in the metabolism of endogenous substrates, natural products and synthetic drugs $(1,2)$ has been described. Many of these differences were shown to occur in rat liver tissue, but mice were also shown to present sex differences in enzyme activity (3-8).

Acetylsalicylic acid (ASA) is the most used drug worldwide. ASA metabolism initiates by hydrolysis promoted by esterases, releasing salicylic acid (SA) from the ester molecule found in different tissues of several species including humans (9-13). We have demonstrated a gender difference in the activity of ASA-esterases in rats (14). This difference is tissue specific and male rats show higher enzyme activity in liver tissue. On the other hand, females show higher enzyme activity in serum. No other sex differences were observed in other tissues assayed (kidneys, brain and adrenal glands).

In the course of our studies on ASA- 
esterase activities we measured enzyme activities in tissues from male and female mice and this paper shows that the pattern of sex differences in ASA-esterase activities is different in rat and mouse tissues. In liver there was no difference in enzyme activity between males and females. However, in kidney, males showed a much higher enzyme activity than females.

\section{Material and Methods}

\section{Subjects}

Naive Swiss male and female albino mice, 3 months old, from our own breeding stock were used in the experiments. After weaning, mice were kept in plastic cages (about 20 animals/cage) with free access to food (Purina ${ }^{\circledR}$ lab chow) and tap water until they were sacrificed. The animals were maintained in a room with controlled temperature $\left(24^{\circ} \mathrm{C}\right)$ on a 12 -h light-dark cycle (lights on from 7:00 a.m. to 7:00 p.m.).

\section{Homogenate preparation}

Mice were sacrificed in the morning by cervical fracture and liver and kidneys excised rapidly and cleaned with cold $1.15 \%$ $\mathrm{KCl}(\mathrm{w} / \mathrm{v})$ to remove surface blood. The organs were wrapped in parafilm followed by aluminum foil and then frozen over dry ice. Tissue was kept at $-20^{\circ} \mathrm{C}$ until the time for assay. Pieces of liver or kidneys were used to prepare the homogenates. The tissue was weighed while frozen and cold $1.15 \%$ $\mathrm{KCl}$ was added at appropriate volumes to give a final $5 \%(\mathrm{w} / \mathrm{v})$ homogenate concentration. Homogenates were prepared using glass homogenizer tubes in a motor-driven Teflon pestle ( 20 strokes). The homogenates were centrifuged for $15 \mathrm{~min}$ at $2,250 \mathrm{~g}$ to clean out cell debris, blood cells and vessels. The supernatants were collected for use in the enzymatic assays. The assays were car- ried out soon after homogenate preparation. Reagents and homogenates were kept at $4^{\circ} \mathrm{C}$ over crushed ice before incubation.

\section{Enzyme assays}

According to Ali and Kaur (9), there are two ASA-esterases, named I and II. We measured the enzymatic formation of SA from ASA by a fluorimetric method (15). Briefly, $20 \mu \mathrm{l}$ of homogenate were incubated in duplicate for $10 \mathrm{~min}$ with $80 \mu \mathrm{l}$ of ASA (diluted in $0.2 \mathrm{M}$ Tris/ $\mathrm{HCl}$ buffer, $\mathrm{pH} 7.4$, for ASAesterase II or $0.2 \mathrm{M}$ acetate buffer, $\mathrm{pH} 5.5$, for ASA-esterase I) at $37^{\circ} \mathrm{C}$ in a shaking water bath. Final ASA concentration in the assay was $8 \mathrm{mM}$. The reaction was stopped by adding $50 \mu 1$ of $10 \%$ trichloroacetic acid (TCA) (w/v). Blanks were also run in duplicate and consisted of adding TCA before incubation. After centrifugation at $2,250 \mathrm{~g}$ at $0^{\circ} \mathrm{C}$ for $15 \mathrm{~min}$, a $20-\mu \mathrm{l}$ aliquot from the clear supernatant was transferred to a tube containing $380 \mu 1$ of buffer used in the incubations. SA fluorescence in the samples was read at 305 (excitation)-405 (emission) nm. The results are reported as nmol SA formed $\min ^{-1} \mathrm{mg}$ protein ${ }^{-1}$. The enzyme assays were carried out in the linear range for both incubation time and protein concentration. Protein was assayed by the method of Lowry et al. (16).

\section{Statistics}

The Student two-tailed $t$-test was used for statistical comparisons $(\mathrm{P} \leq 0.05)$.

\section{Reagents}

The reagents used were analytical grade and were purchased from Sigma Chemical Co., St. Louis, MO, USA. Twice distilled water was used to prepare the solutions. ASA and SA were kindly donated by A Novaquímica, São Paulo, Brazil. 


\section{Results and Discussion}

As can be seen in Figure 1, there was no significant difference between males and females for either enzyme in liver homogenates (ASA-esterase II: $\mathrm{t}=1.54$, d.f. $=8$; ASA-esterase $\mathrm{I}: \mathrm{t}=1.40$, d.f. $=8 ; \mathrm{P}>0.05)$. In contrast, a highly significant difference in ASA-esterases $\mathrm{I}(\mathrm{t}=6.52$, d.f. $=8 ; \mathrm{P}<0.0002)$ and II $(\mathrm{t}=14.7$, d.f. $=8 ; \mathrm{P}<0.0001)$ was obtained in kidney homogenate, with males showing a much higher activity for both enzymes assayed (Figure 2).

The data obtained in the present study showed a highly significant difference in kidney ASA-esterase activity between male and female mice. The differences observed in this study demonstrated that sexual dimorphism in ASA-esterase activities is organ-specific and did not correspond to the sex differences already observed in rats, males showed higher enzyme activity in liver tissue and no difference in kidneys (14).

Sex differences in enzyme activity in mouse tissues have been previously reported. In the liver, females show higher coumarin 7-hydroxylase (4), D-aspartate oxidase (6) and aldehyde oxygenase (8) activities and lower glutathione transferase activity (7), to mention some of the differences observed by other authors. We did not find a difference in ASA-esterase activities between male and female mice in the liver. A lower kidney histidine decarboxylase activity (5) and a higher cytochrome p450 activity (3) have been reported for male mice compared to females. Therefore, our results concerning ASA-esterase activity follow the pattern observed for cytochrome p450 activity.

Sex hormones have been shown to be involved in the control of gender differences in enzyme activity (1). Preliminary data from our laboratory indicate that androgens are involved in maintaining the difference ob-

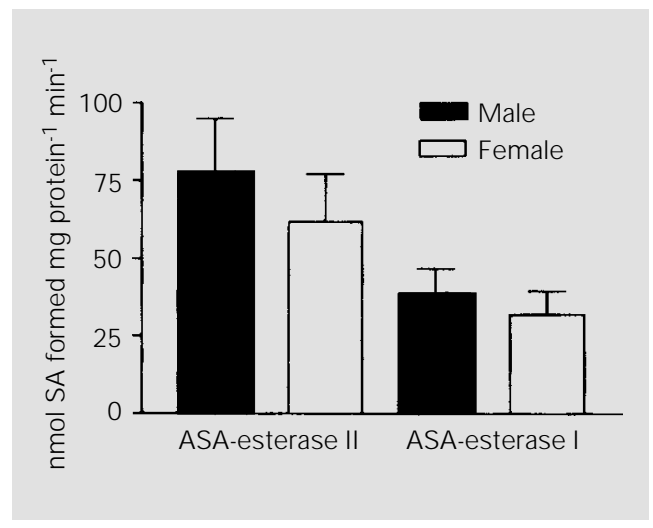

Figure 1 - ASA-esterases I and II activities in liver homogenates from male and female mice. The final ASA concentration in the assay was $8 \mathrm{mM}$. Results are reported as mean $\pm \mathrm{SD}$. $\mathrm{N}=5$ for all groups.

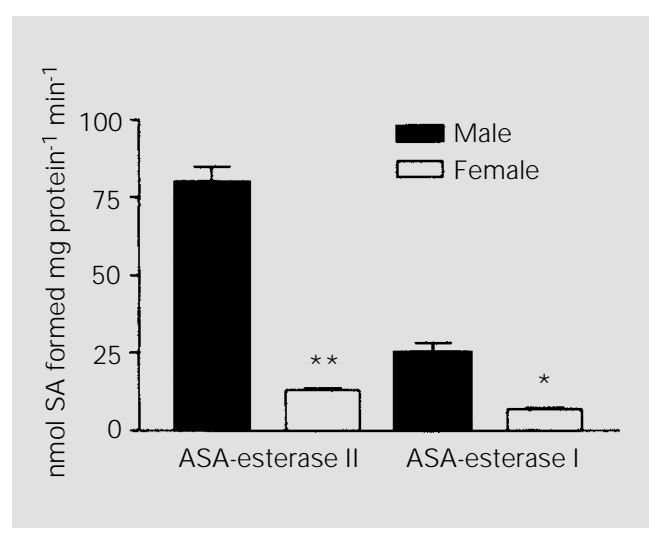

Figure 2 - ASA-esterases I and II activities in kidney homogenates from male and female mice. The final ASA concentration in the assay was $8 \mathrm{mM}$. Results are reported as mean $\pm \mathrm{SD}$. $\mathrm{N}=5$ for all groups. Student t-test, $* \mathrm{P}<0.0002$, ** $\mathrm{P}<0.0001$.

served in kidney ASA-esterase activity between male and female mice.

The endogenous substrate for ASA-esterases has not yet been determined. There are some indications that these enzymes may be involved in the metabolism of long chain thioesters in liver (12). ASA also seems to interfere with essential fatty acid metabolism (17). Therefore, the sex differences in ASA-esterases in mouse kidney described in this paper may reflect differences in lipid metabolism between sexes.

\section{Acknowledgments}

I thank Dr. Deborah Suchecki for help in the preparation of the manuscript and Mrs. Ines Monaco for typing it. 


\section{References}

1. Colby HD (1980). Regulation of hepatic drug and steroid metabolism by androgens and estrogens. Advances in Sex Hormone Research, 4: 27-71.

2. Kato R (1974). Sex-related differences in drug metabolism. Drug Metabolism Reviews, 3: 1-32.

3. Hu JJ, Lee MJ, Vapiwala M, Reuhl K, Thomas PE \& Yang CS (1993). Sex-related differences in mouse renal metabolism and toxicity of acetaminophen. Toxicology and Applied Pharmacology, 122: 16-26.

4. Iersel M van, Walters DG, Price RJ , Lovell DP \& Lake BG (1994). Sex and strain differences in mouse hepatic microsomal coumarin 7-hydroxylase activity. Food and Chemical Toxicology, 4: 387-390.

5. Middleton RJ , Martin SAM \& Bulfield G (1987). A new regulatory gene in the histidine decarboxylase gene complex determines the responsiveness of the mouse kidney enzyme to testosterone. Genetic Research, 49: 61-67.

6. Nagasaki H (1994). Gender-related differences of mouse liver D-aspartate oxidase in the activity and response to administration of d-aspartate and peroxisome proliferators. International J ournal of Biochem- istry, 26: 415-423.

7. Prohaska JR \& Sunde RA (1993). Comparison of liver glutathione peroxidase activity and mRNA in female and male mice and rats. Comparative Biochemistry and Physiology, 105: 111-116.

8. Watanabe $K$, Matsunaga $T$, Narimatsu $S$, Yamamoto I \& Yoshimura H (1992). Sex difference in hepatic microsomal aldehyde oxygenase activity in different strains of mice. Research Communications in Chemical Pathology and Pharmacology, 78: 373-376.

9. Ali B \& Kaur S (1983). Mammalian tissue acetylsalicylic acid esterase(s): identification, distribution and discrimination from other esterases. J ournal of Pharmacology and Experimental Therapeutics, 226: 589594.

10. Howes J F \& Hunter WH (1968). The hydrolysis of acetylsalicylic acid by liver microsomes. J ournal of Pharmacy and Pharmacology, 20: 107-110.

11. Menguy R, Desbaillets L, Masters YF \& Okabe $S$ (1972). Evidence for a sex-linked difference in aspirin metabolism. Nature, 239: 102-103.

12. Mentlein $\mathrm{R}$, Berge RK \& Heymann $\mathrm{E}$ (1985). Identity of purified monoacylglyc- erol lipase, palmitoyl-CoA hydroxylase and aspirin-metabolyzing carboxylesterase from rat liver microsomal fractions. Biochemical J ournal, 232: 479-483.

13. Morgan AM \& Truitt J r EB (1965). Evaluation of acetylsalicylic acid esterase in aspirin metabolism. J ournal of Pharmaceutical Sciences, 54: 1640-1646.

14. Benedito MAC (1998). Gender differences in the activities of aspirin-esterases in rat tissues. Brazilian J ournal of Medical and Biological Research, 31: 1113-1118.

15. Benedito MAC (1997). Fluorimetric determination of tissue distribution and differences between the activity of aspirin esterases I and II in mice and rats. J ournal of Pharmacy and Pharmacology, 49: 273276.

16. Lowry $\mathrm{OH}$, Rosebrough NJ, Farr AL \& Randall RJ (1951). Protein measurement with the folin phenol reagent. J ournal of Biological Chemistry, 193: 265-275.

17. Huang YS, Manku MS, Kent T, Nassar BA \& Horrobin DF (1986). A possible new mechanism of action of aspirin and other non-steroidal antiinflammatory drugs: inhibition of essential fatty acid metabolism. Progress in Lipid Research, 25: 633-635. 